\title{
AKIBAT HUKUM PEMBUBUHAN SIDIK JARI TANGAN PARA PENGHADAP PADA MINUTA AKTA NOTARIS SEBAGAI SEMPURNYA AKTA AUTENTIK MENURUT UU NO 2 TAHUN 2014 JO UU NO 30 TAHUN 2004 TENTANG JABATAN NOTARIS
}

\author{
Khalam Faozy \\ Jawade Hafidz
}

\begin{abstract}
ABSTRAK
Jabatan Notaris terus menerus mengalami perkembangan dan perubahan sesuai dengan perkembangan zaman dalam artian perubahan-perubahan di dalam mempersiapkan para Notaris untuk kepentingan masyarakat, diantaranya diundangkannya perubahan atas Undang-Undang Jabatan Notaris (UUJN). Salah satunya adalah mengenai pengertian tentang minuta akta dan kewajiban Notaris melekatkan cap ibu jari/sidik jari tangan penghadap. Penelitian dengan judul "Akibat Hukum Pembubuhan Sidik Jari Tangan Para Penghadap Pada Minuta Akta Notaris Sebagai Sempurnanya Akta Autentik Menurut Undang-Undang Jabatan Notaris, bertujuan untuk mengetahui prosedur pembubuhan sidik jari tangan para penghadap sebagaimana dinyatakan dalam UUJN, karena bila tidak dilaksanakan Notaris bisa mendapatkan sanksi administratif.

Dalam hal ini pokok permasalahannya yaitu bagaimana prosedur pembubuhan sidik jari tangan para penghadap berdasarkan UUJN dan sampai sejauh mana sanksi yang dikenakan atas akta yang dibuatnya serta sanksi kepada Notaris sendiri jika tidak melakukan kewajiban tersebut.

Metode penelitian yang dipakai adalah penelitian hukum normatif, dengan menggunakan metode analisis kualitatif, yang dilakukan dengan teknik Deskriptif dan Interpretasi, adapun jenis dan sumber datanya menggunakan data sekunder sebagai sumber utamanya, yaitu mempelajari aturan hukum, prinsip hukum maupun doktrin-doktrin hukum guna menjawab mengenai isu hukum yang dihadapi serta melakukan wawancara dengan Notaris/PPAT sebagai nara sumber.

Kesimpulannya adalah Notaris wajib melakukan pembubuhan sidik jari tangan para penghadap sebagaimana tersebut pada UUJN yang mengatur hal tersebut. Apabila Notaris tidak melakukan pembubuhan sidik jari tangan para penghadap dapat terkena sanksi administratif sebagaimana diatur dalam Pasal 16 ayat (11). Terhadap kedudukan aktanya tetap sah dan mempunyai kekuatan pembuktian yang sempurna. Sudah seharusnya Notaris melakukan kewajiban pembubuhan sidik jari tangan para penghadap dalam pembuatan akta, sehingga amanat Pasal 16 ayat (1) huruf c terpenuhi dan akta yang dibuatnya akan lebih sempurna.

Kata Kunci : Pembubuhan Sidik Jari, Minuta Akta
\end{abstract}

\section{A. PENDAHULUAN}

\section{Latar Belakang}

Dalam perubahan UUJN salah satunya mengenai pengertian atau batasan minuta akta. Hal ini sangat penting karena Minuta merupakan sumber utama akta Notaris, tanpa adanya Minuta maka tidak akan ada salinan akta. ${ }^{1}$ Dalam Pasal 1 angka (8) UUJN nomor 30 tahun 2004 menyebutkan bahwa Minuta Akta adalah asli akta Notaris, pengertian Minuta Akta diubah oleh UUJN nomor 2 tahun 2014 yaitu Minuta Akta adalah asli akta yang mencantumkan tanda tangan para penghadap, saksi, dan Notaris, yang disimpan sebagai bagian dari Protokol Notaris.

Ketentuan Pasal 1 angka (8) UUJN nomor 2 tahun 2014 menimbulkan pertanyaan bagi Pejabat Umum (Notaris) dalam membuat akta jika ada penghadap yang tidak bisa tanda tangan atau bisa tanda tangan tetapi tangannya sakit. Ketentuan Pasal 1 angka (8) UUJN nomor 2 tahun 2014 perlu dihubungkan dengan Pasal 16 ayat (1) huruf c yang berkaitan dengan kewajiban Notaris melekatkan sidik jari penghadap pada Minuta Akta. Secara tegas dan jelas Pasal-Pasal

\footnotetext{
${ }^{1}$ Habib Adjie, Menafsirkan Tanda Tangan dan Sidik Jari Pada Minuta Akta Notaris, Majalah Renvoi Nomor 8.128.XI, Januari, 2014, h. 82.
}

tersebut tidak mengatur dan tidak menegaskan tentang prosedur pembubuhan sidik jari penghadap. Sedangkan dalam penjelasan Undang-undangnya kedua Pasal tersebut dinyatakan "cukup jelas". Kewajiban melekatkan sidik jari para penghadap pada Minuta Akta kemudian menjadi tidak jelas ketika para Notaris tidak mempunyai sandaran aturan yang jelas mengenai jari-jari mana saja yang harus diambil sidik jarinya dalam sebuah akta sedangkan dalam penjelasan Undang-undangnya dinyatakan cukup jelas.

Pembubuhan sidik jari pada Minuta Akta akan sangat membantu Notaris bila dikemudian hari ada permasalahan yang terjadi terhadap akta yang dibuatnya. Para penghadap terkadang tidak mengakui pernah bertemu dengan Notaris, bahkan mengingkari tanda tangan yang dibubuhkannya di Minuta Akta sehingga hal ini tentu merepotkan saat ada masalah. Pembubuhan sidik jari para penghadap pada Minuta Akta akan menambah keakuratan identitas para penghadap. Berkaitan dengan hal-hal tersebut diatas, maka penulis terdorong untuk menulis penulisan hukum dengan judul "Akibat Hukum Pembubuhan Sidik Jari Tangan Para Penghadap Pada Minuta Akta Notaris Sebagai Sempurnya Akta Autentik Menurut UU No 2 Tahun 2014 Jo UU No 30 Tahun 2004 Tentang Jabatan Notaris." 


\section{Rumusan Masalah}

a. Bagaimana prosedur pembubuhan sidik jari tangan para penghadap pada Minuta Akta Notaris menurut Undang-undang Nomor 2 Tahun 2014 ?

b. Apa hambatan-hambatan dalam pembubuhan sidik jari para penghadap pada Minuta Akta Notaris dan bagaimana solusinya?

c. Bagaimana akibat hukum terhadap kedudukan Akta dan Notaris yang tidak melakukan pembubuhan sidik jari tangan para penghadap pada Minuta Akta berdasarkan UU Nomor 2 Tahun 2014 jo UU Nomor 30 Tahun 2004 ?

\section{B. PEMBAHASAN}

1. Prosedur Pembubuhan Sidik Jari Tangan Para Penghadap Pada Minuta Akta Notaris Menurut Undang-undang Nomor 2 Tahun 2014

a. Maksud Melekatkan Sidik Jari Pada Minuta Akta Diwajibkannya Notaris melekatkan sidik jari penghadap pada Minuta Akta adalah untuk memberikan kepastian hukum mengenai kebenaran identitas bagi para penghadap didalam akta Notaris, sehingga diharapkan tidak ada penyangkalan dari masing-masing pihak terkait keadaan berhadapan dengan Notaris di dalam akta autentik. Sidik jari (fingerprint) adalah hasil reproduksi tapak jari baik yang sengaja diambil dengan tinta, maupun bekas yang ditinggalkan pada benda karena pernah tersentuh kulit telapak tangan atau kaki. ${ }^{2}$

Sementara bagi Notaris sendiri dengan adanya sidik jari para penghadap tersebut dapat memberikan perlindungan hukum jika dikemudian hari timbul sengketa terkait keadaan berhadapan di dalam akta Notaris, dimana sidik jari tersebut mempunyai arti penting sebagai back-up yang menyatakan bahwa Notaris telah menjalankan fungsi jabatanya sesuai dengan ketentuan peraturan perundang-undangan yang berlaku.

b. Sidik Jari Mana Yang Wajib Dilekatkan Pada Minuta Akta Notaris

Berdasarkan wawancara dengan Untung Dwikorianto, Notaris di Kabupaten Tegal juga sebagai pengurus Majelis Pengawas Daerah (MPD) menjelaskan bahwa terkait amanat Pasal 16 ayat (1) huruf $\mathrm{c}$, dalam setiap pembuatan akta hendaknya Notaris meminta kepada penghadap untuk membubuhkan sidik jari (ibu jari/jempol) kanan dan kiri yang dilekatkan pada Minuta Akta, walaupun tidak ada larangan apabila ada Notaris yang melekatkan sidik jari pada Minuta Akta dengan jari yang lain selain ibu jari, sebab memang tidak ada penjelasan lebih lanjut dalam UUJN mengenai sidik

\footnotetext{
2 Tan Thong Kie, 2007, Studi Notariat dan Serba-serbi Praktek Notaris, Cetakan Pertama, Ichtiar Baru Van Hoeve, Jakarta, h. 480.
}

jari mana yang dilekatkan pada Minuta Akta. ${ }^{3}$ Lain halnya, menurut Filda Vitalia sidik jari penghadap yang digunakan adalah ibu jari sebelah kanan atau sebelah kiri. Sidik jari yang dipergunakan tergantung pada kondisi fisik tangan/sidik jari tangan penghadap dengan menyebutkan nama sidik jari yang digunakannya. ${ }^{4}$

c. Dimana Sidik jari Penghadap Harus Dilekatkan

Menurut Notaris Ramdah, yang juga menjabat sebagai Ketua Pengurus Daerah Ikatan Notaris Indonesia (Pengda INI) Kabupaten Tegal, prosedur pembubuhan sidik jari penghadap dilakukan pada lembar tersendiri atau lembar tambahan dengan mencantumkan judul akta, tanggal, bulan, tahun, jam dan nama para penghadap pada lembar tambahan tersebut. ${ }^{5}$ Hal yang sama juga dinyatakan oleh Notaris Prasetyaningsih, yang juga menjabat sebagai Ketua Ikatan Pejabat Pembuat Akta Tanah (IPPAT) Kabupaten Tegal, menurutnya sidik jari penghadap tersebut dilekatkan pada lembaran kertas tersendiri, hal ini dilakukan karena lembaran yang berisi sidik jari para penghadap tersebut harus dilekatkan bersamaan dengan dijahitnya Minuta Akta, dan pada bagian akhir penutup akta mengenai telah ditandatangani dan dibubuhi sidik jari penghadap dengan keterangan sebagai berikut: ${ }^{6}$

"Setelah akta ini dibacakan oleh saya, Notaris kepada para penghadap, dan para saksi, maka pada ketika itu juga para penghadap membubuhkan tanda tangannya juga membubuhkan sidik jari tangan kiri pada lembaran kertas tersendiri yang dilekatkan pada minuta akta ini, para saksi, dan saya, Notaris menandatanganinya."

d. Penggunaan Sidik Jari Terhadap Penghadap Yang Tidak Bisa Tanda Tangan

Penggunaan sidik jari penghadap pada Minuta Akta berdasarkan Pasal 16 ayat (1) huruf c UUJN bukanlah sebagai pengganti tanda tangan sebagaimana yang dimaksud dalam Pasal 1874 KUHPerdata, menurut G.H.S. Lumban Tobing sidik jari tidak dapat dipersamakan dengan tanda tangan, sidik jari bukan merupakan tanda-tanda huruf (lettertekens), sehingga karenanya tidak memenuhi persyaratan sebagaimana dinyatakan dalam Undang-undang terhadap keharusan penandatanganan nama (het tekenen van de naam). ${ }^{7}$

\footnotetext{
${ }^{3}$ Untung Dwikorianto, Pengurus Majelis Pengawas Daerah (MPD) Kabupaten Tegal, Wawancara, tanggal 16 Januari 2017.

${ }^{4}$ Filda Vitalia, Notaris/PPAT di Jalan Karanganyar Utara Nomor 282, Kecamatan Dukuhturi, Kabupaten Tegal, Wawancara, tanggal 01 Pebruari 2017.

${ }^{5}$ Ramdah, Ketua Pengurus Daerah (Pengda) Ikatan Notaris Indonesia (INI) Kabupaten Tegal, Wawancara, tanggal 06 Pebruari 2017.

${ }^{6}$ Prasetyaningsih, Ketua IPPAT (Ikatan Pejabat Pembuat Akta Tanah) Kabupaten Tegal, Wawancara, tanggal 19 Januari 2017.

${ }^{7}$ G.H.S. Lumban Tobing, 1999, Peraturan Jabatan Notaris, Cetakan Kelima, Erlangga, Jakarta, h. 205.
} 
Dalam hal ini Notaris Evy Indriasari, menjelaskan terhadap penghadap tidak bisa tanda tangan harus menerangkan sebab-sebab yang menjadi halangan tidak dapat membubuhkan tanda tanganya dalam akta, yang dituangkan secara tegas dan jelas pada bagian akhir akta, sebagaimana dinyatakan dalam Pasal 44 ayat (1) dan ayat $(2) .{ }^{8}$ Berikut ini contoh terhadap penghadap yang tidak dapat membubuhkan tanda tangannya dengan alasan karena tangannya cacat atau sakit.

"Setelah akta ini dibacakan oleh saya, Notaris, kepada para penghadap, dan para saksi, maka pada saat itu juga penghadap Tuan A dan Nyonya B, para saksi dan saya, Notaris menandatangani akta ini, sedangkan Penghadap Tuan C menerangkan tidak dapat menandatangani akta ini, oleh karena tangan kanannya sakit patah tulang dan untuk itu penghadap Tuan $\mathrm{C}$ membububuhkan sidik jari jempol tangan kirinya pada lembaran tersendiri yang dilekatkan pada minuta akta ini". 9

2. Hambatan-hambatan Dalam Pembubuhan Sidik Jari Para Penghadap Pada Minuta Akta dan Solusinya

Terkadang Notaris menjumpai penghadap yang tidak mau membubuhkan sidik jarinya pada lembar kertas tersendiri yang telah disediakan oleh Notaris untuk keperluan tersebut dengan alasan sudah membubuhkan tanda tangannya. Hal ini menjadi kendala bagi Notaris manakala penghadap tersebut tidak mau membubuhkan sidik jarinya. Untuk menghadapi persoalan tersebut Notaris harus memberikan penyuluhan hukum terkait pentingnya sidik jari pada Minuta Akta. Pasal 15 ayat (2) huruf e UUJN menyebutkan "Notaris berwenang pula memberikan penyuluhan hukum sehubungan dengan pembuatan akta".

3. Akibat Hukum Terhadap Kedudukan Akta dan Notaris Yang Tidak Melakukan Pembubuhan Sidik Jari Tangan Para Penghadap Pada Minuta Akta Berdasarkan UU Nomor 2 Tahun 2014 jo UU Nomor 30 tahun 2004

a. Akibat Hukum Terhadap Kedudukan Akta Notaris Dalam UUJN tidak ada satu Pasal pun yang menyebutkan akta Notaris yang tidak dilekatkan sidik jari dapat terdegradasi ataupun menurunkan sifat akta Notaris menjadi akta di bawah tangan, hal ini sebagaimana ditegaskan dalam Pasal 16 ayat (11) UUJN, bahwa Notaris yang tidak melaksanakan tugasnya untuk melekatkan sidik jari penghadap pada Minuta Akta

\footnotetext{
${ }^{8}$ Evy Indriasari, Notaris/PPAT, Jalan Raya Suradadi Nomor 18 Suradadi, Kabupaten Tegal, Wawancara, tanggal 25 Januari 2017.

${ }^{9}$ Kalimat ini menurut Evi Indriasari untuk penghadap yang tidak bisa membubuhkan tanda tangan dalam akta karena buta huruf, cacat, lumpuh (kondisi fisik dari tangan penghadap sakit, misal salah satu tangannya patah,dll), tetapi salah satu tangannya bisa membubuhkan sidik jarinya, hal yang demikian sifatnya kondisional.
}

hanya dapat dikenakan sanksi berupa peringatan tertulis, tanpa mengurangi status ataupun sifat dari akta yang dibuat oleh Notaris yang bersangkutan, jadi mengenai hal ini Notaris hanya diberi peringatan tertulis dan aktanya tetap syah dan mengikat serta mempunyai kekuatan pembuktian yang sempurna. Agar akta itu menjadi akta autentik dan tetap syah maka Notaris dalam pembuatan aktanya harus memenuhi syarat-syarat yang dinyatakan dalam Pasal 1868 dan Pasal 1320 KUHPerdata, namun Notaris juga tetap menjalankan kewajiban Pasal 16 ayat (1) huruf c.

b. Sanksi Terhadap Notaris Yang Tidak Melekatkan Lembar Kertas Tersendiri Yang Berisi Sidik jari Para Penghadap Berdasarkan UU Nomor 2 Tahun 2014 jo UU Nomor 30 tahun 2004

Menurut Untung Dwikorianto, Notaris yang tidak melaksanakan ketentuan Pasal 16 ayat (1) huruf c maka Notaris tersebut dapat dikenai sanksi administratif, menurutnya yang berwenang menjatuhkan sanksi adalah Majelis Pengawas Wilayah (MPW), sedangkan Majelis Pengawas Daerah hanya melakukan pemeriksaan dan pembinaan secara langsung dan rutin kepada Notaris, dan jika dalam pemeriksaan ditemukan adanya pelanggaran, maka Majelis Pengawas Daerah (MPD) hanya mengusulkan kepada Majelis Pengawas Wilayah. ${ }^{10}$ Menurut Habib Adjie, ${ }^{11}$ secara garis besar sanksi administratif dapat dibedakan 3 (tiga) macam, yaitu: Sanksi Repartif, Sanksi Puniif dan Sanksi Regresif. Pembubuhan sidik jari penghadap merupakan bagian dari kewajiban Notaris untuk melekatkannya dalam Minuta Akta, meskipun apabila terjadi pelanggaran terhadap kewajiban melekatkan sidik jari penghadap, tidak dapat menyebabkan akta yang dibuat oleh Notaris menjadi terdegradasi menjadi pembuktian akta di bawah tangan, namun demikian Notaris yang melanggar tersebut dapat dijatuhi atau dikenai sanksi administratif.

\section{PENUTUP}

\section{Kesimpulan}

a. Undang-Undang Nomor 2 Tahun 2014 mewajibkan Notaris melekatkan sidik jari para penghadap pada Minuta Akta adalah untuk memberikan kepastian hukum bagi para penghadap di dalam akta Notaris. Prosedur pembubuhan sidik jari dalam UUJN tidak diatur sidik jari mana yang harus dibubuhkan, namun dalam teknisnya bisa menggunakan sidik jari (jempol) tangan kanan atau tangan kiri, bisa juga sidik jari tangan kanan dan kiri, pembubuhan sidik jari tergantung pada kondisi jari penghadap dalam hal ini bersifat kondisional. Pembubuhan

\footnotetext{
${ }^{10}$ Untung Dwikorianto, Op.Cit.

11 Habib Adjie, 2011, Hukum Notaris Indonesia, Tafsir Tematik Terhadap UU No. 30 Tahun 2004 Tentang Jabatan Notaris. Cetakan Ketiga, Refika Aditama, Bandung, h. 211.
} 
sidik jari para penghadap dilakukan pada lembar tersendiri yang telah disiapkan untuk keperluan tersebut oleh Notaris dan dilekatkan pada Minuta Akta.

b. Dalam pelaksanaannya terkadang menemui kendala misal penghadap tidak mau melakukan pembubuhan sidik jarinya karena penghadap merasa sudah membubuhkan tanda tangan, atas kendala tersebut Notaris memberikan penyuluhan hukum terkait pembubuhan sidik jari, dimana sidik jari memiliki fungsi sebagai identifikasi para penghadap manakala terjadi penyangkalanpenyangkalan tentang kehadiran dan tanda tangan yang dilakukan oleh para penghadap karena sidik jari tidak dapat dipalsukan. Dengan melakukan penyuluhan hukum Notaris telah megamalkan Pasal Pasal 15 ayat (2) huruf e UUJN.

c. Terhadap Notaris yang tidak melaksanakan kewajiban melekatkan sidik jari para penghadap pada Minuta Akta tidak mengurangi keabsahan atau otentisitas dari akta yang dibuat oleh Notaris yang bersangkutan, jadi secara normatif tidak membubuhkan sidik jari tersebut tidak memberi pengaruh terhadap kedudukan aktanya, akta Notaris tetap syah dan mengikat serta mempunyai kekuatan pembuktian yang sempurna. Terhadap Notaris yang tidak melaksanakan kewajiban melekatkan sidik jari penghadap pada lembar tersendiri yang dilekatkan pada Minuta Akta sebagaimana diamanatkan dalam Pasal 16 ayat (1) huruf c, maka terhadap pelanggaran tersebut Notaris dapat terkena sanksi administratif sebagaimana diatur dalam Pasal 16 ayat (11) UUJN.

\section{DAFTAR PUSTAKA}

Habib Adjie, Menafsirkan Tanda Tangan dan Sidik Jari Pada Minuta Akta Notaris, Majalah Renvoi Nomor 8.128.XI, Januari, 2014.

Tan Thong Kie, 2007, Studi Notariat dan Serba-serbi Praktek Notaris, Cetakan Pertama, Ichtiar Baru Van Hoeve, Jakarta.

Wawancara dengan Untung Dwikorianto, Notaris/Pejabat Pembuat Akta Tanah, Pengurus Majelis Pengawas Daerah (MPD) Kabupaten Tegal, pada tanggal 16 Januari 2017.

Wawancara dengan Filda Vitalia, Notaris/PPAT di Jalan Karanganyar Utara Nomor 282, Kecamatan Dukuhturi, Kabupaten Tegal, pada tanggal 01 Pebruari 2017.

Wawancara dengan Ramdah, Ketua Pengurus Daerah (Pengda) Ikatan Notaris Indonesia (INI) Kabupaten Tegal, pada tanggal 06 Pebruari 2017.

Wawancara dengan Prasetyaningsih, Ketua IPPAT (Ikatan Pejabat Pembuat Akta Tanah) Kabupaten Tegal, pada tanggal 19 Januari 2017.

G.H.S. Lumban Tobing, 1999, Peraturan Jabatan Notaris, Cetakan Kelima, Erlangga, Jakarta.

Wawancara dengan Evy Indriasari, Notaris/PPAT, Jalan Raya Suradadi Nomor 18 Suradadi, Kabupaten Tegal, pada tanggal 25 Januari 2017.

Habib Adjie, 2011, Hukum Notaris Indonesia, Tafsir Tematik Terhadap UU No. 30 Tahun 2004 Tentang Jabatan Notaris. Cetakan Ketiga, Refika Aditama, Bandung. 